\title{
POLA KOMUNIKASI REMAJA DENGAN IBU, POLA KOMUNIKASI IBU DENGAN GURU, DAN PENCAPAIAN AKADEMIK REMAJA
}

\author{
Herien Puspitawati, Anisyah Kusumawati ${ }^{\star}$ \\ Departemen IImu Keluarga dan Konsumen, Fakultas Ekologi Manusia, Institut Pertanian Bogor, \\ Bogor, 16680, Indonesia
}

*)E-mail: anisyahkusumawati@gmail.com

\begin{abstract}
Abstrak
Penelitian ini bertujuan untuk menganalisis pengaruh karakteristik keluarga, pola komunikasi remaja dengan ibu, pola komunikasi remaja dengan ibu, dan komunikasi ibu dengan guru terhadap pencapaian akademik. Contoh yang ditetapkan memiliki kriteria yakni remaja masih memiliki ibu dan bertempat tinggal bersama ibu berjumlah 71 remaja yang terdiri atas 31 laki-laki dan 40 perempuan, dipilih secara purposive dengan lokasi penelitian di sekolah SMA di Kota Bogor. Data dikumpulkan dengan self-administratered. Hasil penelitian menunjukkan adanya perbedaan yang signifikan dalam komunikasi dimensi orientasi percakapan remaja dengan ibu pada remaja laki-laki dan perempuan, dengan rata-rata jawaban remaja perempuan lebih tinggi dibandingkan dengan remaja laki-laki. Komunikasi remaja dengan ibu masih berdasarkan dimensi orientasi percakapan dan orientasi konformitas terkategori cukup baik. Sementara komunikasi ibu dengan guru menunjukkan hasil yang tergolong masih cukup baik, namun masih ditemukan pula hampir satu perempat komunikasi ibu dengan guru (23,9\%) yang tergolong rendah. Berdasarkan uji regresi menunjukkan faktor yang berpengaruh positif signifikan terhadap prestasi akademik adalah usia ibu dan komunikasi remaja dengan ibu menurut jawaban remaja.
\end{abstract}

Kata kunci: komunikasi remaja dengan ibu, komunikasi ibu dengan guru, pencapaian akademik remaja

\section{Adolescent with Mother Communication Pattern, Mother and Teacher Communication Pattern, and Adolescent Academic Achievement}

\begin{abstract}
This study aimed to analyze the influence of family characteristics, adolescent-mother communication pattern, adolescent-mother communication pattern and teacher-mother communication pattern to academic achievement. The specified sample has the criteria of adolescents still having mothers and live with mothers totaling 71 adolescents consisting of 31 boys and 40 girls, chosen purposively by research sites in high school in Bogor City. Data is collected by self-administrated. The results showed a significant difference in the communication of the orientation dimension of adolescent conversation with mothers in teenage boys and girls, with common answers of teenage girls higher than a male adolescent. Communication of adolescents with mothers is still based on the orientation dimension of the conversation and the orientation of conformity categorized quite well. While mother communication with teacher showed the result which still classified as still good enough, but still found also almost one fourth communications mother with the teacher $(23,9 \%)$ which is low. Based on the regression test showed that factors that have a significant positive effect on academic achievement are maternal age and adolescent communication with mothers according to teenage answers.
\end{abstract}

Keywords: adolescent academic achievement, adolescent-mother communication pattern, teacher-mother communication pattern

\section{PENDAHULUAN}

Sumber daya manusia menjadi bagian penting yang harus ditingkatkan kualitasnya. Adanya peningkatan ini menjadi salah satu tujuan dari Sustainable Development Goals (SDGs) atau keberlanjutan dari Milenium Development Goals (MDGs) terutama dalam bidang pendidikan. Berkaitan dengan hal tersebut, hingga tahun 2030 Indonesia telah berkomitmen untuk meningkatkan kualitas pendidikan sebagai upaya pengembangan kualitas sumber daya manusia. Peningkatan kualitas pendidikan tersebut meliputi berbagai jenjang pendidikan di Indonesia, salah satunya jenjang Sekolah Menengah Atas (SMA) yang menjadi fokus pemerintah untuk mempersiapkan menghadapi persaingan global saat ini.

Siswa pada jenjang Sekolah Menengah Atas (SMA) atau sederajat secara umum berada pada rentang usia enam belas hingga delapan belas tahun yang dikategorikan sebagai seorang remaja. Remaja menjadi bagian dari masa transisi anak-anak menuju dewasa 
(Santrock, 2011). Remaja merupakan masa yang mengalami perubahan besar dalam aspek fisik, kognitif, serta psikososial (Papalia et al., 2011). Aspek pencapaian di sekolah yang berhubungan dengan aspek perkembangan kognitif dan psikososial merupakan hal yang menarik untuk dikaji pada siswa jenjang SMA/sederajat. Hal ini mengingat bahwa remaja sedang belajar untuk mulai mengambil keputusan-keputusan tentang masa depan seperti kuliah, bekerja, dan sebagainya setelah lulus (Desmita, 2009). Pada tahapan ini, kebutuhan remaja untuk mengekspresikan diri dan bersosialisasi dengan teman-teman sebayanya berkembang pesat. Remaja merasa dirinya sudah mandiri, memiliki rasa ingin tahu yang besar, selalu ingin mencoba banyak hal baru yang belum diketahuinya, serta tidak ingin ketinggalan dari teman-temannya. Pada masa ini remaja diberikan kesempatan untuk tumbuh, tidak hanya dalam dimensi fisik, tetapi juga kompetensi kognitif dan sosial, otonomi, harga diri, dan keintiman. Remaja pada fase ini berada di masa kritis karena sebagian remaja mengalami gejolak emosional, konflik dalam keluarga, perilaku gegabah, dan menolak nilainilai orang dewasa (Santrock, 2007).

Selain memasuki fase kritis dalam menyiapkan dirinya menjadi individu dewasa, remaja pada jenjang SMA/sederajat juga tentu saja tetap dituntut untuk memiliki berbagai prestasi di sekolah. Pencapaian prestasi siswa di sekolah meliputi dua aspek yakni pencapaian akademik dan nonakademik. Berdasarkan aturan Permendikbud Nomor 23 Tahun 2016, penilaian hasil belajar peserta didik pada pendidikan dasar dan pendidikan menengah meliputi aspek sikap, pengetahuan, dan keterampilan. Selain itu, perolehan juara atau penghargaan pada aspek akademik dan non akademik atau kegiatan ekstrakurikuler merupakan tolak ukur dari pencapaian pada aspek akademik dan non akademik tersebut. Aktivitas ekstrakurikuler yang berkualitas tersebut dapat mendukung perkembangan remaja karena akan membuat remaja menjadi mentor layaknya orang dewasa yang kompeten dan suportif, meningkat keterlibatannya di sekolah, membuat aktivitas yang lebih menantang dan berarti bagi pengalaman remaja, serta meningkatnya keterampilan remaja (Santrock, 2011). Pencapaian prestasi akademik dan nonakademik tersebut memiliki keterkaitan satu sama lain. Hal tersebut sesuai dengan temuan penelitian sebelumnya yang mengemukakan bahwa partisipasi dalam ekstrakurikuler berhubungan dengan capaian nilai dan keterlibatan sekolah yang lebih tinggi, tidak putus sekolah, meningkatkan kemungkinan meneruskan kuliah, meningkatnya harga diri, dan menurunkan tingkat depresi, kenakalan remaja, dan penyalahgunaan obat terlarang (Fredricks \& Eccles, 2010). Santrok (2007) menjelaskan bahwa prestasi menjadi persoalan yang lebih serius pada tahapan remaja karena dengan prestasi yang dicapainya saat ini dapat membuat remaja mulai merasakan bahwa hidup sekarang harus lebih bersungguhsungguh. Remaja juga mulai memiliki pandangan tentang keberhasilan dan kegagalan saat ini dapat menjadi prediksi bagi keberhasilan dan kegagalan di masa depan ketika dewasa nanti. Hanya saja, seringkali tuntutan pencapaian di berbagai bidang pelajaran yang semakin tinggi menyebabkan minat sosial remaja dapat berkurang dikarenakan sebagian besar alokasi waktu yang dimilikinya digunakan untuk mengerjakan tugas-tugas akademik di sekolah.

Berdasarkan data dari Pemerintah Kota Bogor (2016), diperoleh informasi bahwa Kota Bogor menempati peringkat pertama rata-rata Ujian Nasional tingkat SMK dan pada tahun 2015 rata-rata Ujian Nasioanl tingkat SMA menempati pertama juga di Provinsi Jawa Barat. Data nilai rata-rata hasil Ujian Nasional (UN) Sekolah Menengah Atas (SMA) di Kabupaten Bogor yaitu 58,46 menunjukkan capaian masih di bawah nilai rata-rata UN Kota Bogor yaitu sebesar 70,25 (Kemendiknas, 2015). Hal tersebut mengindikasikan bahwa siswa di Kota Bogor memiliki prestasi akademik yang cukup baik sehingga perlu dipertahankan dan ditingkatkan melalui kerjasama antara orang tua dan sekolah.

Prestasi atau pencapaian tersebut tidak terlepas dari peran keluarga. Faktor keluarga berperan dalam pembentukan diri remaja khususnya pada aspek akademik. Secara sinergi, hubungan interpersonal dan pertukaran sosial pada remaja tidak luput dari faktor lingkungan keluarga khususnya melalui komunikasi keluarga. Komunikasi dalam keluarga yang terjadi antara anak dengan orang tua terdiri atas dua aspek yakni conversation-orientation dan conformityorientation (Ritchie \& Fitzpatrick 2012). Conversation-orientation berarti menggunakan pengaruh orang tua untuk menjalankan konformitas anak yang jelas pada orang tua. Selain itu, conformity-orientation yang berarti mendorong percakapan menjadi percakapan terbuka dalam bertukar ide dan perasaan. Komunikasi yang kurang efektif akan 
menimbulkan konflik dalam keluarga. Secara langsung maupun tidak langsung, konflik hubungan orang tua dengan remaja berkontribusi terhadap masalah perilaku remaja (Dekovic' et al., 2004). Menurut Puspitawati (2008), perilaku yang negatif seperti tingkat agresifitas dan kenakalan remaja dapat dicegah dengan komunikasi efektif. Sebaliknya, peningkatan motivasi anak untuk berprestasi, peningkatan harga diri, dan penekanan kenakalan remaja dipengaruhi oleh komunikasi keluarga yang baik (Firdanianty et al., 2016). Hasil penelitian yang dilakukan mengungkapkan resiliensi akademik dipengaruhi secara signifikan oleh pola komunikasi keluarga (Jowkara et al., (2011). Hal tersebut dikarenakan pola komunikasi remaja dengan keluarga yang baik akan mendorong remaja untuk bersikap terbuka kepada ibunya. Firdanianty et al. (2016) menyatakan bahwa komunikasi yang harmonis antara orang tua dan remaja diyakini dapat membawa kepada hubungan interpersonal yang baik sehingga terjadi pertukaran sosial yang baik pula. Selain itu, pencapaian akademik remaja juga memiliki hubungan yang positif dengan keterlibatan orang tua yang dilakukan di rumah (Castro et al., 2015).

Menurut Porumbu dan Necşoi (2013) prestasi akademik secara konsisten semakin meningkat dengan dukungan dari gaya pengasuhan orang tua yang demokratis, harapan orang tua yang tinggi terhadap hasil belajar, dan komunikasi antara orang tua dengan guru mengenai kemajuan atau kesulitan remaja. kerja sama orang tua dan sekolah penting dilakukan untuk mengembangkan strategi pendidikan dan bertanggungjawab atas keberhasilan remaja. Hubungan remaja dengan orang tua yang positif ditandai dengan konflik yang rendah, tingginya tingkat dukungan, dan komunikasi terbuka. Remaja yang menyatakan mempunyai hubungan yang baik dengan salah satu orang tua, akan memiliki kesehatan fisik dan mental yang baik. Sebaliknya, remaja yang sering mengalami konflik dengan orang tua, ditambah rendahnya dukungan orang tua, besar kemungkinan terlibat dalam perilaku yang berisiko, seperti penggunaan narkoba, minum alkohol, dan merokok, serta harus berjuang dengan gejala depresi (Sacks et al., 2014).

Selain komunikasi antara remaja dengan orang tua, terdapat faktor lain yang diyakini dapat meningkatkan pencapaian prestasi remaja di sekolah. Menurut Chairani et al. (2009) pembentukan perilaku siswa di sekolah dilatarbelakangi oleh komunikasi antara orang tua dan guru. Komunikasi yang baik antara guru dengan orang tua pun memengaruhi keinginan dan kemampuan mengerjakan PR, perilaku di kelas, dan partisipasi aktif di kelas (Kraft \& Dougherty, 2012). Hubungan guru dan siswa yang harmonis juga merupakan faktor yang memengaruhi prestasi akademik siswa (Ndege et al., 2015). Ibu sebagai pengasuh utama merupakan tokoh p[enting bagi anak dalam membangun komunikasi antara orang tua dengan sekolah. Sinergisme antara ibu dan sekolah merupakan faktor lain yang berhubungan positif dengan pencapaian akademik maupun nonakademik remaja di sekolah. Secara simultan dan berkesinambungan, sinergisme keluarga dan sekolah dilakukan sebagai upaya antara kedua pihak dalam menjalankan pendidikan holistik terhadap anak di rumah maupun di sekolah (Puspitawati \& Sarma, 2015). Salah satu bentuk sinergisme tersebut ialah komunikasi antara ibu dengan guru. Terkait interaksi antar ibu dengan guru, terdapat penelitian yang menunjukkan bahwa ibu yang lebih sering berhubungan dengan sekolah dapat lebih baik dalam mengembangkan strategi belajar anak (Stevenson \& Baker, 1987)

Indonesia masih termasuk kategori level bawah terkait pencapaian akademik berdasarkan survey yang dilakukan pada banyak negara. Berbagai faktor yang melatarbelakangi permasalah pada pencapaian akademik tersebut, salah satu faktornya ialah keterlibatan orang tua. Hubungan yang terjadi ialah positif signifikan yang berarti semakin besar keterlibatan orang tua akan memengaruhi performa pelajar SMA (Jeynes, 2008). Sinergisme antara sekolah, keluarga, dan masyarakat pun berhubungan erat dengan kehadiran yang menjadi aspek pencapaian di sekolah. Hal tersebut akan membantu remaja untuk memiliki performa sekolah yang lebih baik, terutama dalam pencapaian ujian, menurunkan kemungkinan angka drop out, menurunkan kemungkinan konsumsi merokok, alkohol, dan obat-obatan terlarang (Sheldon, 2010). Secara lebih spesifik, sinergisme dalam bentuk komunikasi antara ibu dengan guru memegang peranan yang juga penting. Hal itu karena keefektifan komunikasi kedua belah pihak tersebut dapat meningkatkan pembelajaran siswa (Clay, 2005). Oleh sebab itu, penelitian mengenai pola komunikasi remaja dengan ibu, pola komunikasi ibu dengan guru, pencapaian akademik dan nonakademik remaja di SMA penting untuk dilakukan. Keterkaitan antar variabel topik penelitian tersebut masih cukup 
jarang dikaji secara bersamaan sehingga peneliti merasa perlu untuk mengkaji lebih dalam. Berdasarkan uraian di atas, penelitian ini bertujuan untuk: 1) mengidentifikasi karakteristik keluarga, karakteristik remaja, pola komunikasi remaja dengan ibu, dan pola komunikasi ibu dengan guru pada pencapaian akademik remaja perempuan dan remaja lakilaki di SMA; dan 2) menganalisis pengaruh karakteristik keluarga, pola komunikasi remaja dengan ibu, tipologi keluarga berdasarkan pola komunikasi remaja dengan ibu, dan komunikasi ibu dengan guru terhadap pencapaian akademik remaja perempuan dan remaja laki-laki di SMA.

\section{METODE}

Desain penelitian ini adalah cross-sectional study dengan metode self-administered. Kota Bogor dipilih sebagai tempat penelitian karena terkategori dalam tiga besar peringkat pencapaian akademik tertinggi di Jawa Barat serta 20 besar di Indonesia. Lokasi penelitian adalah salah satu SMA negeri yang ada di wilayah Kota Bogor. Sekolah tersebut dipilih karena memiliki pencapaian akademik yang cukup baik dan merupakan sekolah percontohan projek kemitraan antara orang tua dengan sekolah dari Kementerian Pendidikan dan Kebudayaan RI. Penelitian dilakukan dari mulai Februari hingga Juni 2017.

Populasi dalam penelitian ini ialah seluruh siswa SMA terpilih. Kriteria contoh dalam penelitian ini ialah siswa kelas XII sekolah terpilih beserta ibunya; yang ada di kelas XII Biologi, XII Fisika-Kimia, dan XII Fisika. Dari ketiga kelas tersebut diperoleh contoh sebanyak 109 siswa. Namun pada akhirnya contoh didapatkan ialah sebanyak 71 siswa beserta ibunya karena faktor kriteria dan kesanggupan menjadi contoh. Kriteria contoh yang ditetapkan ialah siswa yang masih memiliki dan menetap bersama ibu di rumah. Data primer dikumpulkan dengan cara selfadministratered menggunakan kuesioner pada remaja dan ibu yang meliputi karakteristik remaja, karakteristik keluarga, pola komunikasi remaja dengan ibu, pola komunikasi ibu dengan guru remaja di SMA. Selain itu, pencapaian siswa berupa pencapaian akademik diperoleh dari pengumpulan data sekunder. Kuesioner untuk jawaban remaja diisi di sekolah sedangkan kuesioner berdasarkan jawaban ibu dititipkan pada remaja untuk disampaikan kepada ibu, diisi ibu, dan kemudian dikembalikan kepada peneliti.
Pola komunikasi remaja dengan ibu adalah dari Ritchie dan Fitzpatrick (2012) yang menyatakan bahwa komunikasi dalam keluarga yang terjadi antara anak dengan orang tua terdiri atas dua aspek yakni conversation-orientation dan conformityorientation. Conversation-orientation berarti menggunakan pengaruh orang tua untuk menjalankan konformitas anak yang jelas pada orang tua. Instrumen yang digunakan untuk mengukur pola komunikasi remaja dengan ibu berdasarkan jawaban remaja dan ibu menggunakan Revised Family Communication Pattern (RFCP) dari Ritchie \& Fitzpatrick (1990) dengan Cronbach's alpha 0,814. Kuesioner ini terdiri atas 23 pertanyaan yakni 14 pertanyaan adalah dimensi percakapan dan 9 pernyataan ialah dimensi konformitas.

Konsep utama pola komunikasi orang tua guru ialah berdasarkan Berger (1991) dalam Clay (2005) menjelaskan bahwa terdapat dua jenis komunikasi antara orang tua dengan guru yakni one-way communication dan two-way communication. Selain itu, konsep yang digunakan ialah sinergisme yang dilakukan oleh orang tua dengan sekolah menurut Puspitawati dan Sarma (2015). Pola komunikasi ibu dengan guru diukur menggunakan instrumen yang memodifikasi beberapa alat ukur antara lain Family Involvement Survey (2009) dan Survey on Family And School Partnerships In Public Schools k-8 dengan Cronbach's alpha instrumen adalah 0,902. Instrumen yang digunakan berisi 21 pertanyaan. Selain itu, instrumen untuk mengukur pola komunikasi keluarga terkait sekolah menggunakan Family Involvement Questionnaire for High School (FIQ-HS) dengan Cronbach's alpha 0,802 yang dikembangkan oleh Hoover-Dempsey \& Sandler (2005). Jumlah pertanyaan yang digunakan ialah 8 pertanyaan yang kemudian dilebur menjadi dua dimensi percakapan dan konformitas. Pertanyaan yang dilebur tersebut terdiri aats 4 pertanyaan yang dimasukkan kedalam dimensi orientasi percakapan dan 4 pertanyaan kedalam dimensi orientasi konformitas. Seluruh instrumen tersebut menggunakan skala likert mulai dari 1 (tidak pernah), 2 (kadang-kadang), 3 (sering), dan 4 (selalu).

Pengukuran pencapaian akademik remaja ditentukan dengan melihat nilai rapor yang diperoleh selama satu semester terakhir yakni semester lima atau semester satu di kelas XII pada mata pelajaran matematika, fisika, kimia, dan biologi. Pencapaian akademik Menurut Permendikbud Nomor 23 Tahun 2016, 
penilaian hasil belajar peserta didik pada pendidikan dasar dan pendidikan menengah meliputi empat aspek, yakni aspek sikap spiritual, sikap sosial, pengetahuan, dan keterampilan (Kemendikbud, 2016). Pengukuran variabel pencapaian akademik berupa rataan nilai dikategorikan menjadi sangat baik $(87,80-100,00)$, baik $(62,80-87,70)$, cukup (37,80-62,79), dan kurang (25,00$37,79)$. Analisis deskriptif digunakan untuk menggambarkan karakteristik remaja, karakteristik keluarga, pola komunikasi remaja dengan ibu, dan pola komunikasi ibu dengan guru. Analisis inferensia dilakukan dengan uji beda independent sample $t$-test, dan uji regresi linier berganda.

Skor/nilai variabel-variabel yang diteliti dikategorikan dengan menggunakan cut-off point yang terdiri atas kategori rendah $(0,00$ $40,00)$, sedang $(40,10-70,00)$, dan tinggi (70,10-100,00). Cut off point tersebut dilebur menjadi dua pengkategorian yakni rendahsedang dan tinggi untuk mendapatkan hasil tipologi berdasarkan pola komunikasi remaja dengan ibu.

\section{HASIL}

\section{Karakteristik Remaja}

Remaja dalam penelitian ini adalah siswa SMA kelas XII dengan rata-rata usia 17,29 tahun. Ibu yang dijadikan responden penelitian ratarata berusia 46,31 tahun sedangkan ayah remaja rata-rata berusia 50,28 tahun. Sebanyak tiga orang ayah dari remaja laki-laki telah meninggal dunia sedangkan keseluruhan remaja perempuan masih memiliki orang tua lengkap. Besar keluarga keduanya sama yaitu rata-rata 5 orang. Hampir setengah ibu $(40,8 \%)$ berpendidikan terakhir SMA, sedangkan jumlah terbanyak ayah terkategori pendidikan terakhir D4/S1. Hasil penelitian menunjukkan bahwa lebih dari setengah ibu $(59,2 \%)$ tidak bekerja atau menjadi ibu rumah tangga, sedangkan satu dari empat ayah $(25,4 \%)$ dari remaja dalam penelitian ini bekerja di sektor swasta. Sebagian besar remaja perempuan maupun laki-laki $(71,8 \%)$ berasal dari keluarga dengan kategori pendapatan per kapita tidak miskin dengan rata-rata pendapatan per kapita per bulan adalah Rp998.925,38. Hasil uji beda tidak menemukan adanya perbedaan nyata pada peubah karakteristik keluarga berdasarkan jenis kelamin remaja (Tabel 1).
Tabel 1 Rata-rata dan uji beda karakteristik keluarga berdasarkan jenis kelamin remaja

\begin{tabular}{lrrr}
\hline \multirow{2}{*}{ Peubah } & \multicolumn{2}{c}{ Rata-rata } & $\begin{array}{c}p- \\
\text { value }\end{array}$ \\
\cline { 2 - 3 } & $\begin{array}{c}\text { Remaja laki- } \\
\text { laki }\end{array}$ & $\begin{array}{c}\text { Remaja } \\
\text { Perempuan }\end{array}$ & val \\
\hline $\begin{array}{l}\text { Usia Ayah } \\
\text { (tahun) }\end{array}$ & 50,00 & 50,48 & 0,734 \\
$\begin{array}{l}\text { Usia lbu } \\
\text { (tahun) }\end{array}$ & 47,03 & 45,75 & 0,339 \\
$\begin{array}{l}\text { Besar } \\
\text { Keluarga } \\
\text { (orang) }\end{array}$ & 4,77 & 4,65 & 0,609 \\
$\begin{array}{l}\text { Pendapatan } \\
\begin{array}{l}\text { Perkapita } \\
\text { (rupiah) }\end{array}\end{array}$ & $1.271 .827,96$ & $1.429 .583,33$ & 0,513 \\
\hline
\end{tabular}

\section{Pola Komunikasi Remaja dengan Ibu}

Komunikasi dalam keluarga yang terjadi antara remaja dengan ibu terdiri atas dua aspek yakni conversation-orientation dan conformityorientation (Ritchie \& Fitzpatrick, 2012).

\section{Orientasi Percakapan}

Penelitian ini menemukan adanya perbedaan yang signifikan dalam komunikasi remaja dengan ibu pada jawaban remaja laki-laki dan perempuan (Tabel 2). Remaja perempuan lebih sering mengatakan sesuatu yang dipikirkan dibandingkan dengan remaja lakilaki yang cenderung jarang terbuka mengenai pikirannya. Hasil penelitian juga menunjukkan adanya perbedaan nyata namun tidak terlalu terpaut jauh berdasarkan jawaban ibu. Pembicaraan rencana serta harapan-harapan mengenai keluarga untuk masa depan merupakan hasil tertinggi yang diperoleh. Hasil orientasi percakapan pada remaja menyatakan bahwa setengah remaja terkategori sedang dalam hal komunikasi terbuka dengan orang tua, khususnya dengan ibu. Jawaban ibu pun menyatakan berada pada intenstas yang sedang. Pada dimensi percakapan ditemukan adanya perbedaan yang signifikan antara remaja laki-laki dan remaja perempuan. Remaja laki-laki cenderung untuk jarang mengungkapkan perasaannya pada ibu dibandingkan dengan remaja perempuan. Hal tersebut karena remaja perempuan bisa bersikap lebih terbuka pada ibu dibandingkan dengan laki-laki. Namun menurut jawaban remaja, orang tua jarang menyatakan hal tersebut. Perbedaan jawaban itu diduga karena remaja dengan orang tua memiliki cara pandang yang berbeda. Orang tua cenderung overestimate terhadap komunikasi yang dilakukan dengan remaja. 
Tabel 2 Sebaran dimensi orientasi percakapan berdasarkan kategori jawaban remaja dan ibu serta nilai rata-rata, minimal, maksimal, dan uji beda

\begin{tabular}{|c|c|c|c|}
\hline \multirow[t]{2}{*}{ Kategori } & $\begin{array}{l}\text { Remaja } \\
\text { Laki-laki }\end{array}$ & $\begin{array}{c}\text { Remaja } \\
\text { Perempuan }\end{array}$ & Total \\
\hline & $\%$ & $\%$ & $\%$ \\
\hline \multicolumn{4}{|c|}{ Jawaban Remaja } \\
\hline Rendah & 19,4 & 17,5 & 18,3 \\
\hline Sedang & 67,7 & 45,0 & 54,9 \\
\hline Tinggi & 12,9 & 37,5 & 26,8 \\
\hline Total & 100,0 & 100,0 & 100,0 \\
\hline $\begin{array}{l}\text { Rata- } \\
\text { rata } \pm S D\end{array}$ & $1,935 \pm 0,573$ & $2,200 \pm 0,723$ & $2,085 \pm 0,670$ \\
\hline $\begin{array}{l}\text { Min- } \\
\text { Maks }\end{array}$ & $1-3$ & $1-3$ & $1-3$ \\
\hline$p$-value & & & \\
\hline \multicolumn{4}{|c|}{$\begin{array}{l}p \text {-value } \\
\text { Jawaban Ibu }\end{array}$} \\
\hline Rendah & 9,7 & 2,5 & 5,6 \\
\hline Sedang & 64,5 & 47,5 & 54,9 \\
\hline Tinggi & 25,8 & 50,0 & 39,4 \\
\hline Total & 100,0 & 100,0 & 100,0 \\
\hline $\begin{array}{l}\text { Rata- } \\
\text { rata } \pm S D\end{array}$ & $2,161 \pm 0,582$ & $2,475 \pm 0,554$ & $2,338 \pm 0,584$ \\
\hline $\begin{array}{l}\text { Min- } \\
\text { Maks }\end{array}$ & $1-3$ & $1-3$ & $1-3$ \\
\hline$p$-value & \multicolumn{2}{|c|}{$0,081^{*}$} & \\
\hline
\end{tabular}

\section{Orientasi Konformitas}

Antara remaja laki-laki dan perempuan pada dimensi konformitas tidak terdapat adanya perbedaan yang signifikan. Berdasarkan sebaran tertinggi pada jawaban remaja secara keseluruhan menunjukkan remaja berharap untuk dapat menuruti peraturan ibu di rumah. Sebanyak tiga perempat remaja terkategori sedang menurut jawaban remaja. Orientasi konformitas pada remaja perempuan lebih tinggi terkategori sedang $(82,5 \%)$ sedangkan remaja laki-laki yang terkategori sedang $(64,5 \%)$. Akan tetapi pada kategori tinggi lebih tinggi remaja laki-laki $(29,0 \%)$ dibandingkan dengan remaja perempuan (15,0\%). Hasil penelitian juga menunjukkan bahwa lebih dari setengah jawaban ibu pun serupa yakni berada pada intensitas yang sedang. Remaja merasa masih kurang pada aspek konformitas karena jumlah remaja yang terkategori tinggi masih lebih sedikit dibandingkan remaja yang terkategori sedang dan rendah. Berdasarkan sebaran jawaban remaja juga diketahui orang tua selalu berharap remaja tidak berdebat dengan orang dewasa $(60,6 \%)$, dan remaja juga diharapkan selalu setuju dengan pendapat orang tua daripada mencari risiko yang membuat orang tua marah $(52,1 \%)$. Hasil ini berarti berkomunikasi yang mengedepankan penyesuaian dan hirarki dengan ibu masih cukup sedikit.
Tabel 3 Sebaran dimensi orientasi konformitas berdasarkan kategori jawaban remaja dan ibu serta nilai rata-rata, minimal, maksimal, dan uji beda

\begin{tabular}{|c|c|c|c|}
\hline \multirow{2}{*}{ Kategori } & $\begin{array}{l}\text { Remaja } \\
\text { Laki-laki }\end{array}$ & $\begin{array}{c}\text { Remaja } \\
\text { Perempuan }\end{array}$ & Total \\
\hline & $\%$ & $\%$ & $\%$ \\
\hline \multicolumn{4}{|c|}{ Jawaban Remaja } \\
\hline Rendah & 6,5 & 2,5 & 4,2 \\
\hline Sedang & 64,5 & 82,5 & 74,6 \\
\hline Tinggi & 29,0 & 15,0 & 21,1 \\
\hline Total & 100,0 & 100,0 & 100,0 \\
\hline $\begin{array}{l}\text { Rata- } \\
\text { rata } \pm S D\end{array}$ & $1,290 \pm 0,461$ & $1,425 \pm 0,500$ & $2,169 \pm 0,477$ \\
\hline Min-Maks & $1-3$ & $1-3$ & $1-3$ \\
\hline$p$-value & & 34 & \\
\hline \multicolumn{4}{|c|}{ Jawaban Ibu } \\
\hline Rendah & 0,0 & 0,0 & 0,0 \\
\hline Sedang & 54,8 & 65,0 & 60,6 \\
\hline Tinggi & 45,2 & 35,0 & 39,4 \\
\hline Total & 100,0 & 100,0 & 100,0 \\
\hline $\begin{array}{l}\text { Rata- } \\
\text { rata } \pm S D\end{array}$ & $1,48 \pm 0,508$ & $1,50 \pm 0,506$ & $2,39 \pm 0,492$ \\
\hline Min-Maks & $2-3$ & $2-3$ & $2-3$ \\
\hline$p$-value & \multicolumn{2}{|c|}{0,398} & \\
\hline Keterangan & $\begin{array}{l}\text { *signifikan } \mathrm{p} \\
\text { pada } \mathrm{p} \text {-value }\end{array}$ & $\begin{array}{l}\mathrm{p} \text {-value }<0 \text {, } \\
05\end{array}$ & $1 ;{ }^{* \star}$ signifikan \\
\hline
\end{tabular}

\section{Pola Komunikasi lbu dengan Guru}

Hasil penelitian menunjukkan tidak adanya perbedaan yang signifikan antara komunikasi ibu remaja laki-laki dan ibu remaja perempuan dengan guru. Hasil penelitian juga memperlihatkan bahwa sekitar empat dari sepuluh ibu $(63,4 \%)$ memiliki komunikasi yang sedang dengan guru (Tabel 4). Pada kategori sedang tersebut, ibu dengan anak remaja perempuan memiliki persentase yang lebih tinggi $(67,5 \%)$ dibandingkan ibu dengan anak remaja laki-laki. Selain itu, masih terdapat ibu yang terkategori komunikasi yang rendah dengan guru anaknya di sekolah yakni sebesar 23,9 persen dengan persentase ibu dengan anak remaja perempuan lebih tinggi persentasenya $(22,5 \%)$. Namun, kategori tinggi untuk komunikasi ibu dengan guru, ibu dengan anak remaja laki-laki memiliki persentase yang lebih tinggi $(16,1 \%)$ dibandingkan ibu dengan anak remaja perempuan (10,0\%). Berdasarkan jawaban remaja orang tua selalu menceritakan masa lalu kehidupan di sekolahnya (23,9\%) dan orang tua sering mendiskusikan karir masa depan yang menarik bagi saya (54,9\%). Sementara menurut jawaban orang tua sering mendiskusikan kehidupan setelah SMA $(38,0 \%)$ dan bertanya kegiatan di sekolah $(35,2 \%)$. 
Tabel 4 Sebaran pola komunikasi ibu dengan guru berdasarkan kategori serta nilai rata-rata, minimal, maksimal, dan uji beda

\begin{tabular}{|c|c|c|c|}
\hline Kategori & $\begin{array}{l}\text { Remaja } \\
\text { Laki-laki }\end{array}$ & $\begin{array}{c}\text { Remaja } \\
\text { Perempuan }\end{array}$ & Total \\
\hline & $\%$ & $\%$ & $\%$ \\
\hline Rendah & 25,8 & 22,5 & 23,9 \\
\hline Sedang & 58,1 & 67,5 & 63,4 \\
\hline Tinggi & 16,1 & 10 & 12,7 \\
\hline Total & 100,0 & 100,0 & 100,0 \\
\hline $\begin{array}{l}\text { Rata- } \\
\text { rata } \pm S D\end{array}$ & $1,80 \pm 0,60$ & $2,00 \pm 0,57$ & $1,36 \pm 0,485$ \\
\hline Min-Maks & $1-3$ & $1-3$ & $1-3$ \\
\hline$p$-value & \multicolumn{2}{|c|}{0,741} & \\
\hline
\end{tabular}

\section{Pencapaian Akademik Remaja}

Hasil menunjukkan pada pencapaian kategori akademik sangat baik, remaja perempuan memiliki persentase yang lebih tinggi $(62,5 \%)$ dibandingkan dengan remaja laki-laki. Namun, pada kategori pencapaian akademik baik, remaja laki-laki memiliki persentasi lebih tinggi dibandingkan dengan remaja perempuan. Adapun terdapat remaja laki-laki sebanyak 45,1 persen dengan persentase lebih besar $(54,8 \%)$ dibandingkan dengan perempuan $(37,5 \%)$. Berdasarkan nilai rata-rata, remaja perempuan memiliki nilai yang lebih tinggi $(88,10)$ dibandingkan dengan remaja laki-laki $(87,39)$. Oleh karena itu, dapat dinyatakan bahwa dalam penelitian ini secara umum remaja perempuan memiliki capaian akademik yang lebih baik dibandingkan dengan remaja laki-laki.

\section{Pengaruh Karakteristik Remaja, Pola Komunikasi Remaja dengan Ibu, dan Pola Komunikasi Ibu dengan Guru terhadap Pencapaian Akademik Remaja}

Uji regresi linier berganda digunakan untuk menganalisis pengaruh karakteristik keluarga, karakteristik remaja, pola komunikasi remaja dengan ibu, dan pola komunikasi ibu-guru terhadap pencapaian akademik. Model yang dibangun dalam penelitian ini (Tabel 5) menunjukkan bahwa pengujian variabel bebas terhadap pencapaian akademik remaja dalam penelitian ini telah signifikan pada selang kepercayaan 95 persen. Koefisien determinasi atau Adjusted $R$ Square model yang dibangun yakni sebesar 0,136. Hal tersebut menunjukkan bahwa sebesar peluang pengaruh karakteristik, pola komunikasi remaja dengan ibu, dan pola komunikasi ibu dengan guru terhadapi pencapaian akademik remaja adalah 13,6 persen. Sementara itu, sisanya sebesar 86,4 persen pencapaian akademik remaja dipengaruhi oleh faktor-faktor lain di luar variabel bebas penelitian.

Hasil uji pada Tabel 5 menunjukkan bahwa pencapaian akademik remaja sangat dipengaruhi oleh salah satu karakteristik keluarga yakni usia ibu. Pengaruhnya yakni positif signifikan terhadap pencapaian akademik $(\beta=0,314, p<0,05)$. Artinya, setiap kenaikan satu tahun usia ibu akan menaikkan pencapaian akademik sebesar 0,314 poin. Temuan ini menunjukkan semakin matang usia ibu maka dapat meningkatkan prestasi akademik remaja. Komunikasi remaja dengan ibu pada jawaban remaja memiliki pengaruh positif signifikan terhadap pencapaian akademik $(\beta=0,214, p<0,05)$. Artinya, setiap kenaikan satu skor komunikasi remaja dengan ibu yang dipersepsikan remaja akan menaikkan pencapaian akademik sebesar 0,214 poin. Temuan ini menunjukkan bahwa pencapaian akademik akan lebih tinggi diraih oleh remaja ketika orientasi percakapan dan konformitas pun tinggi karena komunikasi remaja dengan ibu menurut jawaban remaja dengan pencapaian akademik memiliki pengaruh positif signifikan.

Tabel 5 Koefisien regresi karakteristik keluarga, karakteristik remaja, pola komunikasi remaja dengan ibu, pola komunikasi ibu dengan guru, dan pencapaian akademik remaja

\begin{tabular}{|c|c|c|c|}
\hline \multirow{2}{*}{ Variabel } & \multicolumn{3}{|c|}{ Pencapaian Akademik } \\
\hline & (B) & $(\beta)$ & Sig. \\
\hline Constant & 1,260 & & 0,049 \\
\hline $\begin{array}{l}\text { Jenis kelamin } \\
\text { (1=laki-laki, } \\
2=\text { perempuan })\end{array}$ & 0,157 & 0,157 & 0,184 \\
\hline Usia lbu (tahun) & 0,028 & 0,314 & $0,014^{* *}$ \\
\hline $\begin{array}{l}\text { Pendidikan Ibu } \\
\text { (tahun) }\end{array}$ & 0,028 & 0,067 & 0,625 \\
\hline $\begin{array}{l}\text { Pendapatan } \\
\text { perkapita (rupiah) }\end{array}$ & $-1,030 \mathrm{E}-7$ & $-0,205$ & 0,106 \\
\hline $\begin{array}{l}\text { Komunikasi remaja } \\
\text { dengan ibu jawaban } \\
\text { remaja (indeks) }\end{array}$ & 0,009 & 0,214 & $0,093^{*}$ \\
\hline $\begin{array}{l}\text { Komunikasi remaja } \\
\text { dengan ibu jawaban } \\
\text { ibu }\end{array}$ & 0,008 & 0,117 & 0,394 \\
\hline $\begin{array}{l}\text { Komunikasi ibu } \\
\text { dengan guru } \\
\text { (indeks) }\end{array}$ & $-0,002$ & $-0,056$ & 0,655 \\
\hline Uji F & & 2,569 & \\
\hline Sig. & & 0,022 & \\
\hline R Square & & 0,471 & \\
\hline Adjusted R Square & & 0,136 & \\
\hline
\end{tabular}




\section{PEMBAHASAN}

Perspektif struktural fungsional memiliki aspek penting yakni pada setiap keluarga yang sehat terdapat pembagian peran/fungsi keluarga yang jelas. Fungsi tersebut terpola dalam struktur hirarkis yang harmonis dan adanya komitmen terhadap pelaksanaan peran/fungsi tersebut (Puspitawati, 2012). Pendekatan teori tersebut digunakan untuk menganalisis peran dan keberfungsian anggota keluarga sehingga dapat menjaga keutuhan keluarga dan masyarakat (Puspitawati, 2012). Salah satu cara untuk mempertahankan keutuhan keluarga yaitu dengan menjalin hubungan komunikasi yang optimal. Koerner dan Fitzpatrick (2004) menyatakan bahwa komunikasi keluarga adalah suatu proses keluarga berbagi mengenai realitas sosial dan secara luas didefinisikan menjadi empat tipe yang dikalsifikasikan berdasarkan perilaku komunikasi secara jelas berupa kelebihan maupun kekurangan pada area kehidupan keluarga mencakup resolusi konflik atau pengambilan keputusan.Komunikasi keluarga pada dasarnya dipengaruhi pula oleh karakteristik remaja, seperti usia dan tahap perkembangan remaja (Kraft \& Dougherty, 2012). Pola komunikasi yang terjalin antara orang tua khususnya ibu dan remaja penting dioptimalkan untuk mencapai salah satunya prestasi akademik remaja.

Menurut Setiono (2011), setiap anggota keluarga memerlukan cara untuk berkomunikasi yang baik dan benar sehingga terhindar dari kesalahpahaman. Kesalahan komunikasi antaranggota keluarga terjadi apabila pihak penyampai pesan tidak jelas dalam menyampaikan pesan, tidak tepat cara menyampaikan pesan, kurang mempertimbangkan waktu yang tepat untuk menyampaikan sesuatu, dan kurang memperhitungkan kondisi pihak anggota keluarga. Sebaliknya, dari pihak anggota keluarga penerima pesan dapat pula menyebabkan kesalahan komunikasi. Hal itu terjadi apabila penerima pesan bersikap kurang terbuka terhadap gagasan anggota keluarga yang lain, sudah mempunyai pandangan tertentu, dan tidak mempertimbangkan kondisi atau situasi dari penyampai pesan. Remaja membentuk ikatan yang kuat dengan orang tua melalui komunikasi dalam keluarga. Komunikasi keluarga merupakan cara utama bagi anak untuk belajar berkomunikasi dan menafsirkan perilaku orang lain, mengalami emosi, dan bertindak dalam hubungan orang tua dan anak (Firdaniaty et al., 2016)
Menurut Papalia et al. 2011) masa remaja awal bagian dari fase ketika berhadapan konflik dengan orang tua lebih banyak dialami dibandingkan saat masa anak-anak. Hal ini disebabkan beberapa faktor diantaranya perubahan biologis, pubertas, perubahan kognitif yang meliputi semakin meningkatnya idealisme dan penalaran logis, perubahan sosial yang berfokus pada kemandirian dan identitas, perubahan kebijaksanaan dan harapan-harapan pada orang tua. Orang tua dapat terlibat dan memengaruhi prestasi pendidikan anak dengan melibatkan diri dalam pendidikan anak. Adapun dapat dilakukan dengan bertindak sebagai penasihat bagi anak-anak dan memberi kesan pada guru dengan keseriusan target pendidikan keluarga. Lingkungan keluarga menjadi bagian yang berperan penting untuk membentuk dan mengarahkan perkembangan mental dan perilaku individu, melalui pemberian contoh dan teladan yang sesuai dengan kehidupan sehari-hari (Ponzetti, 2005; Küçük et al., 2012). Selain itu, sekolah dengan lingkungan yang positif (lingkungan yang penuh dengan kepedulian dan rasa hormat; aman secara sosial, emosi, dan fisik) memungkinkan anak untuk tidak hanya mempelajari kemampuan akademik tetapi juga keterampilan sosial sehingga sekolah dengan lingkungan yang positif mampu menurunkan risiko munculnya berbagai perilaku negatif pada anak (Lehr, 2005; Wang et al., 2010; Aldridge \& Ala'l, 2013; Sojourner, 2014).

Berdasarkan hasil penelitian pola komunikasi remaja dengan ibu masih terkategori cukup baik. Hasil penelitian menunjukkan bahwa sebagian remaja laki-laki masih kurang terbuka dengan ibunya. Keterbukaan dalam berkomunikasi salah satu sarana memperhatikan remaja sehingga dapat mengembangkan kognitifnya. Perkembangan kognitif remaja dipengaruhi secara signifikan oleh stimulasi orang tua (Houghughi \& Long, 2004). Menurut Caro et al. (2011), performa di sekolah memiliki keterikatan dengan komunikasi didalam keluarga antara remaja dengan orang tua. Komunikasi yang efektif tersebut merupakan salah satu fungsi dalam keluarga yang memiliki struktur untuk mencapai tujuan keseimbangan, dalam hal ini terkait tujuan pencapaian pada performa remaja di sekolah. Komunikasi di dalam keluarga dapat memotivasi remaja untuk berprestasi, meningkatkan harga diri, dan menekan kenakalan remaja (Firdanianty et al., 2016). Tipe keluarga ideal secara berkala dapat mengembangkan komunikasi terbuka untuk mencari ide baru namun tetap 
memelihara hirarki dan memelihara nilai-nilai dalam keluarga karena sama-sama mengedapankan orientasi konformitas dan percakapan. Anak pada tipe keluarga tersebut akan belajar untuk mengadopsi nilai-nilai dalam keluarga namun tetap dapat independen (Koerner \& Fitzpatrick, 2004). Sikap independen yang berkaitan dengan perilaku belajar karena remaja dapat pengembangan strategi belajar bagi dirinya karena memiliki kepercayaan diri dalam membuat keputusan. Remaja yang mengatur pembelajaran mereka sendiri memiliki kecenderungan lebih besar mencoba berprestasi dan lebih cenderung sukses ketimbang siswa yang tidak yakin dengan kemampuannya sendiri (Papalia et al., 2011).

Hasil penelitian ini menemukan bahwa komunikasi antara ibu dengan guru sebagian besar terkategori cukup baik. Hal tersebut karena orang tua telah mempercayai remaja untuk dapat menentukan pilihan sendiri. Sikap tersebut berdampak pada intensitas komunikasi terkait akademik remaja, salah satunya ialah ibu hampir tidak pernah menanyakan PR. Bentuk komunikasi satu arah pada penelitian ini, ibu dari remaja laki-laki maupun perempuan sepakat menyatakan selalu menerima laporan pencapaian akademik secara berkala. Kesadaran ibu dalam meningkatkan komunikasi yang efektif dengan guru sebagai upaya untuk meningkatkan pencapaian akademik remaja tersebut. Bentuk komunikasi dua arah yakni penyampaian pesan yang disampaikan pihak sekolah melalui telepon atau grup media sosial, ibu menyatakan memiliki intensitas yang sering dalam memahaminya. Selain itu, ibu dari remaja laki-laki memiliki intensitas yang lebih sering dalam menerima respon yang baik dari sekolah dibandingkan dengan remaja perempuan. Sinergisme keluarga dan sekolah dilakukan sebagai upaya dalam menjalankan pendidikan holistik terhadap anak di rumah dan di sekolah secara simultan dan berkesinambungan (Puspitawati \& Sarma, 2015). Komunikasi antara ibu dengan guru dipengaruhi oleh kemampuan interpersonal sehingga meningkatkan pembelajaran siswa (Clay, 2005). Adapun kemampuan interpersonal berkaitan dengan kemampuan dan keterampilan remaja untuk dapat bersosialisasi dengan lingkungan sekitarnya. Kemampuan remaja dalam bersosialisasi dan berinteraksi dengan guru dan teman-teman di sekolah dapat membantu proses pembelajaran dengan saling bertukar pengetahuan sehingga meningkatkan prestasi akademik. Hasil penelitian Daniyati dan Sugiman (2015) menyatakan bahwa kemampuan interpersonal berhubungan positif dengan prestasi belajar matematika pada siswa. Pencapaian prestasi akademik juga dipengaruhi keinginan dan kemampuan mengerjakan PR, perilaku di kelas, dan partisipasi aktif di kelas, meningkatkan motivasi ekstrinsik siswa, selfefficacy (Kraft \& Dougherty, 2012). Komunikasi yang efektif pada kedua pihak tersebut tidak hanya memengaruhi hubungan harmonis diantara keduanya namun juga dapat memiliki pengaruh positif pada siswa. Komunikasi antara ibu dan guru berperan dalam pembentukan perilaku siswa (Chairani et al., 2009). Beberapa penelitian lain menjelaskan bahwa remaja menganggap komunikasi dengan ibu lebih mudah dan sering memilih untuk berbicara dengan ibu mengenai hal-hal yang penting (Levin \& Currie, 2010). Ibu dipandang lebih berpengaruh karena menghabiskan waktu lebih banyak dengan remaja dibandingkan ayah (Heller et al., 2006). Temuan-temuan dalam penelitian ini menegaskan komunikasi remaja dengan ibu merupakan faktor penting dalam mengoptimalkan perkembangan remaja dalam mencapai prestasi akademiknya.

Selain itu, penelitian ini menemukan bahwa usia ibu memiliki pengaruh yang positif signifikan terhadap prestasi akademik dalam model regresi yang dibangun. Temuan ini menunjukkan ibu yang memiliki usia yang lebih matang akan memiliki banyak pengalaman dalam membimbing sehingga pencapaian akademik remaja pun meningkat. Ibu yang telah matang dari sisi usia akan mengoptimalkan upayanya dalam melakukan interaksi dan terlibat aktivas bersama dengan remaja sehingga mendorong pencapaian prestasi remaja. Kematangan usia ibu akan menyebabkan ibu dalam melakukan komunikasi dengan remaja semakin baik dan optimal khususnya dalam meminimalisir adanya kesalahpahaman berkomunikasi. Faktor ibu ditemukan lebih signifikan dalam penelitian ini yang juga menegaskan bahwa ibu berinteraksi lebih sering dengan anak, terutama dalam proses yang berhubungan dengan perawatan dan tugas rutin keluarga daripada yang ayah lakukan (McCarthy \& Edwards, 2011). Komunikasi remaja dengan ibu memiliki pengaruh yang signifikan positif terhadap pencapaian akademik remaja dalam model regresi yang dibangun. Hal tersebut sesuai dengan penelitian yang dilakukan oleh Firdanianty et al. (2016) yang menyatakan bahwa komunikasi di dalam keluarga tersebut dapat memotivasi remaja untuk berprestasi, meningkatkan harga diri, dan menekan 
kenakalan remaja, serta menyatakan prestasi belajar dipengaruhi langsung maupun tidak langsung dari pola komunikasi remaja dengan keluarga. Hasil penelitian Mushtaq dan Khan (2012) juga menyatakan bahwa komunikasi merupakan salah satu faktor yang memengaruhi prestasi akademik. Siswa yang mempunyai kemampuan komunikasi yang baik memiliki prestasi akademik yang tinggi. Penelitian memiliki keterbatasan dalam dikarenakan hanya mengukur berdasarkan perspektif ibu saja. Selain itu, hasil penelitian tidak dapat digeneralisasikan pada sampel yang lain, karena metode yang digunakan purposive.

\section{SIMPULAN DAN SARAN}

Pencapaian akademik remaja lebih dari setengahnya $(54,8 \%)$ terkategori sangat baik. Usia ayah $(88,7 \%)$ dan ibu $(85,9 \%)$ sebagian besar tergolong dewasa madya dengan ratarata tingkat pendidikan ayah ialah S1/D4 dan ibu ialah SMA. Seperempatayah (25,4\%) bekerja sebagai pegawai swasta dan setengah ibu $(59,2 \%)$ bekerja sebagai lbu Rumah Tangga. Rata-rata besar keluarga remaja ialah 5 orang. Selain itu, sebagian besar keluarga $(71,8 \%)$ tergolong ke dalam keluarga tidak miskin. Komunikasi remaja dengan ibu masih terkategori cukup baik; baik secara total maupun di masing-masing dimensi. Selain itu, komunikasi ibu dengan guru juga menunjukkan hasil yang tergolong masih cukup baik, namun tidak sedikit $(23,9 \%)$ yang tergolong rendah. Hasil penelitian menunjukkan bahwa dimensi orientasi percakapan antara remaja dengan ibu berbeda nyata antara remaja laki-laki dan perempuan. Sementara itu, peningkatan usia ibu dan komunikasi remaja dengan ibu secara nyata mampu meningkatkan pencapaian akademik remaja.

Berdasarkan hasil penelitian, ibu diharapkan dapat meningkatkan intensitas komunikasi dengan guru karena komunikasi antara ibu dengan guru sebagian besar terkategori rendah. Hal ini dapat dilakukan dengan mengoptimalkan pertemuan orang tua dan guru untuk meningkatkan prestasi akademik remaja. Usia ibu berpengaruh positif terhadap prestasi akademik, sehingga diharapkan ibu dapat melakukan komunikasi dan stimulasi yang optimal dengan remaja sehingga prestasi akademik remaja dapat meningkat. Bagi sekolah, komunikasi dengan ibu khususnya terkait akademik sebaiknya lebih dikembangkan, misalnya dengan menjadwalkan pertemuan rutin dengan orang tua untuk membahas kemajuan belajar anak, melakukan diskusi pengasuhan yang baik, dan membuat lingkungan belajar siswa yang kondusif. Bagi pemerintah, diharapkan dapat merealisasikan program kemitraan sekolah dan orang tua sehingga dapat mengoptimalkan prestasi akademik remaja.

\section{DAFTAR PUSTAKA}

[KEMENDIKNAS] Kementerian Pendidikan Nasional. (2015). Nilai Ujian Nasional SMA, SMK, dan Sederajat Berdasarkan Wilayah Indonesia. Jakarta: Kementerian Pendidikan Nasional.

[Pemkot] Pemerintah Kota Bogor. (2014). Rata-rata UN SMAK Bogor Tertinggi SeJabar. [diakses] https://kotabogor.go.id/index.php/show post/detail/3887: pada tanggal: $30 \mathrm{Mei}$ 2018

Aldridge, J., \& Ala'l, K. (2013). Assessing students' views of school climate: developing and validating the What's Happening In This School? (WHITS) questionnaire. Improving Schools. 16(1): 47-66.

Caro, D. H. (2011). Parent-child performance. Journal for Educational Research. 3 (2):15-37.

Castro, M., Expósito-Casas, E., López-Martín, E., Lizasoain, L., Navarro-Asencio, E., \& Gaviria, J. L. (2015). Parental involvement on student academic achievement. Educational Research Review February (14): 33-46

Chairani, M., Wiendijarti, I., Novianti, D. (2009). Komunikasi interpersonal guru dan orang tua dalam mencegah kenakalan remaja pada siswa (studi deskriptif pada siswa kelas XI SMA Kolombo Sleman). Jurnal Komunikasi. 7 (02) :143-151.

Clay. (2005). Communicating with parents: strategies for teachers. School Community Journal. 16 (1): 117-129

Daniati, N. A., \& Sugiman. Hubungan antara komunikasi verbal, kemampuan interpersonal, dan minat belajar dengan prestasi belajar matematika. Pythagoras: Jurnal Pendidikan Matematika, 10(1):50-60, tersedia pada: http://journal.uny.ac.id/index.php/pythag oras 
Dekovic', M., Wissink, I. B., \& Meijer, A. M. (2004). The role of family and peer relations in adolescent antisocial behaviour: comparison of four ethnic groups. Journal of Adolescence. 27: 497-514

Firdanianty., Lubis, D. P., Puspitawati, H., Susanto. D. (2016). Pola komunikasi remaja dan pengaruhnya terhadap kecerdasan emosional siswa SMA di Kota Bogor. Jurnal komunikasi. 1 37-47

Fredricks, E. (2010). Breadth of Extracurricular participation and adolescent adjustment among africanamerican and european-american youth. Journal of Research Adolescent. 20 (2) : 307-333.

Heller, S. R., Robinson, L. C., Henry, C. S., \& Plunkett, S. W. (2006). Gender differences in adolescent perceptions of parent adolescent openness in communication and adolescent empathy. Marriage \& Family Review. 40(4): 103-122.

Hoover-Dempsey, K. V., \& Sandler, H. M. (2005). The Social Context of Parental Involvement: A Path to Enhanced Achievement. Study 4 School Report. Vanderbilt University

Jeynes, W. H. (2008). Effects of parental involvement on experiences of discrimination and bullying. Marriage \& Family Review, 43:3-4, 255-268, DOI:10.1080/01494920802072470

Jowkar, B., Kohoulat, N., \& Zakeri, H. (2011). Family communication patterns and academic resilience. Social and Behavioral Sciences. 29:87-90

Koerner, A. F., Fitzpatrick, M. A. (2004). Communication in Intact Families on Handbook of Family Communication (pp. 177-195). Mahwah, NJ: L. Erlbaum Associates.

Kraft, \& Dougherty. (2012). The effect of teacher-family communication on student engagement. Journal of Research on Educational Effectiveness. 6(3): 199-222.

Küçük, S., Habaci, M., Göktürk, T., Ürker, A.,\& Adiguzelli, F. (2012). Role of family, environment and education on the personality development. Middle-East Journal of Scientific Research. 12(8): 1078-1084.
Levin, K. A., \& Currie, C. (2010). Family structure, mother-child communication, fatherchild communication, and adolescent life satisfaction: A crosssectional multilevel analysis. Health Education. 110(3): 152-168.

McCarthy, J. R., Edwards, R. (2011). Key Concept in Family Studies. London: Sage.

Ndege, W. M., Bosire, K., \& Ogeta, N. (2015). Factors affecting academic performance in day secondary school in Borabu Disctrict in Kenya. International Journal of Current Business and Social Sciences. 1(3): 1-13.

Papalia, D., Olds, W., Feldman, R. D. Diterjemahkan oleh A.K.Anwar (2011). Developmental Psychology. Jakarta: Kencana

Ponzetti, J.J. Jr. (2005). The family as moral center: An evolutionary hermeneutic of virtue in family studies. Journal of Research in Character Education. 3(1): 61-70.

Porumbu, D., \& Necşoi, D. V. (2013). Relationship between parental involvement attitude and children's school achievements. Journal of Social and Behavioral Science. (76): 706-710.

Puspitawati H. (2012). Gender dan Keluarga: Konsep dan Realita di Indonesia. PT IPB Press. Bogor.

Puspitawati, H. (2008). Pengaruh komunikasi keluarga, lingkungan teman dan sekolah terhadap kenakalan pelajar dan nilai pelajaran pada sekolah menengah di Kota Bogor. Jurnal IImiah Pekerja Sosial. Vol. 7 (2).287-306

Puspitawati, H.,\& Sarma, M. (2015). Sinergisme Keluarga dan Sekolah Dalam Mewujudkan Kualitas Sumber daya Manusia. Bogor : IPB Press.

Ritchie L. D., Fitzpatrick M. A. (1990). Family communication patterns: Measuring Interpersonal perceptions of interpersonal relationship.17(4):523-544

Sacks, V., Moore, K.A., Shaw, A.,\& Cooper, P.M. (2014). The Family Environment and Adolescent Well-Being. Research Brief Child Trends, Publication

Santrock J.W. (2011) Remaja. Buku 2. Benedictine Widyasinta. penerjemah. Jakarta (ID): Erlangga. Terjemahan dari: Adolescence. Ed ke-11. 
Santrock, J. W. (2011). Life Span Development. Jakarta (ID) : Erlangga.

Sheldon, S. B. (2010). Improving student attendance with school, family, and community partnerships. Journal of Educational Research. Vol 100 (5): 267275.

Stevenson, D. L., Baker, D. P. (1987). The family-school relation and the child's school performance. Reasearch in Child Development. 58 (5): 1348-1357
Wang, M.T, Selman, R.L., Dishion, T.J., \& Stormshak, E.A. (2010). A tobit regression analysis of the covariation between middle school students' perceived school climate and behavioral problems. J Res Adolesc. 20(2): 274286.

Zhang, Q. (2008) Family types and children's socio-communicative style: a chinese investigation, Journal of Intercultural Communication Research, 37(3), 157167 